I

\title{
ResearchArticle
}

\section{Identification of restorers and maintainers lines in rice (Oryza sativa L.)}

S.B. Verma

\section{SUMMARY}

Three cytoplasmic genetic male sterile $(\mathrm{cm})$ lines, mainly IR 58025 A, PMS 8 A and PMS 10 A were crossed with eight indigenous rice genotypes of saline alkaline and scented high yielding to identify their prospective restorers, partial restorers and effective maintainers. Study of $\mathrm{F}_{1}^{\mathrm{S}}$ enabled to identify fourteen restorers ten partial restorers to CMS lines. None of the lines were found to be partial maintainers and effective maintainers for the CMS lines.

Key Words : Rice, CMS lines, Restorers, Maintainers

How to cite this article : Verma, S.B. (2019). Identification of restorers and maintainers lines in rice (Oryza sativa L.). Internat. J. Plant Sci., 14 (1): 25-27, DOI: 10.15740/HAS/IJPS/14.1/25-27, Copyright@ 2019: Hind Agri-Horticultural Society.

Article chronicle : Received : 16.10.2018; Revised : 06.12.2018; Accepted : 15.12.2018 